medical student and understood these issues without sentimentality.

Dawkins wants it both ways. He wants to function as Apollonius, disabusing his reader of the various magical-seeming possibilities of astrology, coincidence, relativism and misleading metaphor. But he also wants to assert the inevitably wonder-enhancing power of scientific insight; he does not want to destroy the beauty of Lamia. He is dismayed by the poet's question:

Do not all charmsfly

At the mere touch of cold philosophy?

There was an awful rainbow once in heaven:

We know her woof, her texture; she is given

In the dull catalogue of common things

In "Lamia" the question is loaded with the dismay of the poet struggling to locate truth. "Lamia" is no ignorant rejection of natural philosophy's reductionism; it is a painful and sinewy debate, more toughminded than the softened prose in which Dawkins ends Unweaving the Rainbow: "A Keats and a Newton, listening to each other, might hear the galaxies sing". Or, as Keats recognized, the galaxies may not be singing. Gillian Beer is at Clare Hall, University of Cambridge, Herschel Road, Cambridge CB3 $9 A L, U K$.

\section{The unread menace}

\section{Measuring Minds: Henry Herbert Goddard and the Origins of A merican Intelligence Testing edited by Leila Zenderland \\ Cambridge University Press: 1998. 448 pp. $\mathfrak{E} 45, \$ 64.95$}

\section{Roy Porter}

Henry Herbert Goddard won a somewhat dubious immortality by coming up with the term 'moron' - meant to identify from among the mass of the 'feeble-minded' a "person of attested mental development with an intelligence comparable to that of the normal child between 8 and 12 years inclusive". From such a coinage, there is much that could be easily — and correctly - predicted about the convictions and career of one of the most influential US psychologists of the first half of this century (he died in 1957 at the ripe old age of 91). Goddard, as one might guess, was one of the vociferous cohort of scientists preoccupied with human 'degeneration' and seeking ways of averting the 'threat' posed by 'defectives' to American society.

But, as Leila Zenderland demonstrates in a well-researched if somewhat hefty biography, Goddard, although a keen eugenist, resists being reduced to the reactionary eugenist villain who looms large in recent historiography. After all, he thought of his politics as being progressive - he even favoured the New Deal - and he was opposed to the more extreme measures (such as the 'lethal chamber') being touted to deal with the 'menace', and even rather doubtful about the desirability of surgical sterilization.

Goddard, who around the time of the First World War was America's most widelyread psychologist, saw his career in terms of chance and happenstance, and there is an element of truth in that view. Born in 1866 into a typically pious New England Quaker family, he attended a minor college (Haverford) and drifted around for a while on the fringes of higher education until, like so many others of his generation, he was fired by G. Stanley Hall of Clark University in Massachusetts. It was Hall who persuaded Freud to make his one and only trip to the United States. In Hall's inspiring vision, the up-and-coming discipline of evolutionary psychology was destined, in effect, to replace religion. It would bestow on society a body of scientific values suitable for combating the ills of modern times and grant to individuals a means to self-awareness and self-improvement. Goddard was converted.

Convinced that the 'unfit' constituted not only a pressing problem but a group on whom he could practise his new-found professional expertise, Goddard took employment in 1906 in a 'training school' for the 'feeble-minded' - Vineland, in rural New Jersey. Two years later, while travelling in Europe, he had the good fortune to be one of the first to grasp the significance of the intelligence tests newly developed by Alfred Binet, which launched the concept of 'mental age' within the framework of a general mental test.

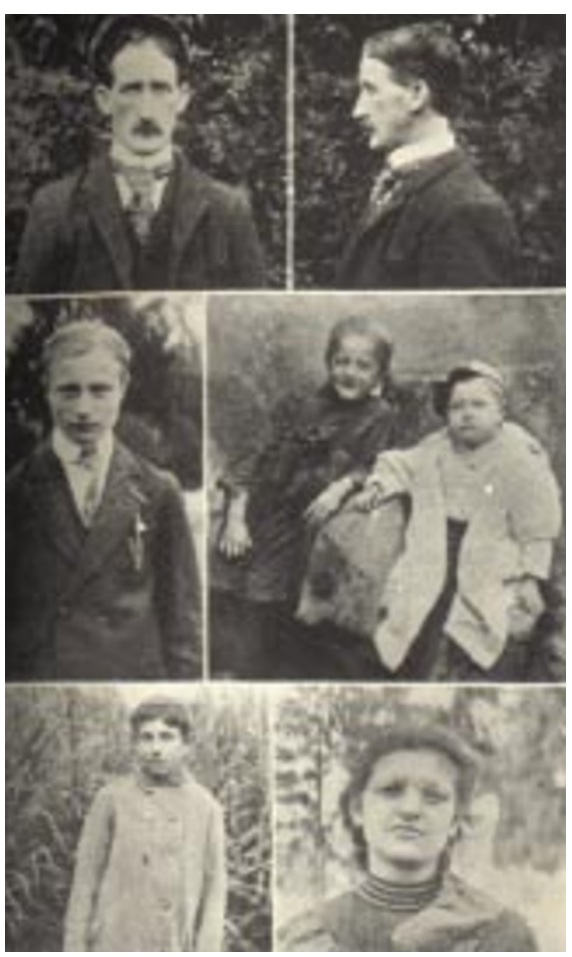

The 'feeble-minded' underclass: these 'cases' of Goddard's were said to have a mental age of seven.
Confusion had long reigned when it came to the tricky matter of classifying the different grades of 'idiots', to say nothing of disputes - between doctors, educationists and institutional superintendents - as to the cause and proper treatment of the condition. An energetic member of the 'FeebleMinded Club', Goddard was able to persuade first himself and then his colleagues that the Binet test - that is, a psychological approach — would provide solutions as to what should be done with these problem people.

Like many of his ilk who were, by training, pedagogues rather than physicians, Goddard was initially optimistic about what could be achieved: the 'feeble-minded' would prove educable, leading to "a better mind if not a perfect mind", if only one researched the right way to go about it. But bitter experience seemed to prove the opposite. And so his thinking underwent a seachange, from a position not unsympathethic to the contribution of the environment ('nurture') in producing and rectifying defectives, to one that insisted on the cardinal role played by heredity ('nature').

Familiarizing himself with Mendelian genetics, Goddard began to investigate the family backgrounds of institutional populations and professed surprise on finding a vast submerged iceberg of imbecilism. Degeneracy evidently ran in families, and marriages between epileptics, alcoholics, criminals, syphilitics, nymphomaniacs and all other "defectives, dependants and delinquents" only served to make bad worse down the generations. The defectives were not only different; they might even constitute a 'moron majority'.

These findings were written up in 1912 in a book that became a bestseller: The Kallikak Family: A Study in the Heredity of FeebleMindedness. The name was fictitious (it is a compound of the Greek words for beautiful and bad), but the family was real. Goddard had traced its bifurcated pedigree (some 480 descendants) from its eighteenth-century roots. One branch was thoroughly respectable, while the other (descended from the first Kallikak's illegitimate offspring) engendered a succession of defectives, criminals, prostitutes and so forth. The book entered the culture, and it even achieved a reprint in Nazi Germany. A more conventional statement of his research findings then appeared in Feeble-Mindedness: Its Causes and Consequences, published in 1914.

The rest of Goddard's lengthy career was dedicated to further exposure of such undesirables and to the application of psychometric testing to all walks of life - from immigration controls to the army - in the belief that intelligence differentials were crucial to the understanding and resolution of social problems.

In Goddard's eyes, 'the facts' had thus 
forced him to become a eugenist. Experience equally seemed to suggest what should be done. Sterilization was, he thought, a suspect option - after all, civil liberties were central to American values. The way forward must lie in the institutional segregation of the unfit. Not only would that prevent defectives from breeding and create a supportive and humane environment for them, but it would provide a superb "human laboratory" (Goddard's standard phrase) for researching their mentalities and laying bare the pathology of the human psyche.

It would, as Zenderland persuasively argues, be misleading to cast Goddard simply as some sort of stock bigot. Doubtless he believed there was some kind of underclass, but he was remarkably free of racial and colour prejudice - what he mainly feared were poor whites. He is best seen primarily as a representative of an emergent cadre of experts, scientists and professional administrators, anxious to establish a place in the sun for themselves as the new priesthood serving a secularizing society, preaching the gospel not of laissez-faire capitalism but of informed social responsibility.

Zenderland does not pretend that her protagonist was a very profound or original thinker. Although a passionate champion of ubiquitous intelligence testing, Goddard never seems to have thought deeply about what precisely it was that was being measured. He was a doer, a technician, lucky enough to hold in his hands, in the Binet test, that device utterly appropriate to the needs of classification and control in a mass society. $\square$ Roy Porter is at the Wellcome Institute for the History of Medicine, 183 Euston Road, London NW1 2BE, UK.

\section{Not black and white}

\author{
Melanis m: Evolution in Action \\ by Michael E. N. Majerus \\ Oxford University Press: 1998. 338 pp. $£ 55$, \\ \$105 ( $h b k$ ), £23.95, \$45 (pbk)
}

\section{Jerry A.Coyne}

From time to time, evolutionists re-examine a classic experimental study and find, to their horror, that it is flawed or downright wrong. We no longer use chromosomal polymorphism in Drosophila pseudoobscura to demonstrate heterozygous advantage, flower-colour variation in Linanthus parryae to illustrate random genetic drift, or the viceroy and monarch butterflies to exemplify Batesian mimicry. Until now, however, the prize horse in our stable of examples has been the evolution of 'industrial melanism' in the peppered moth, Biston betularia, presented by most teachers and textbooks as the paradigm of natural selection and evolution occurring within a human lifetime. The reexamination of this tale is the centrepiece of

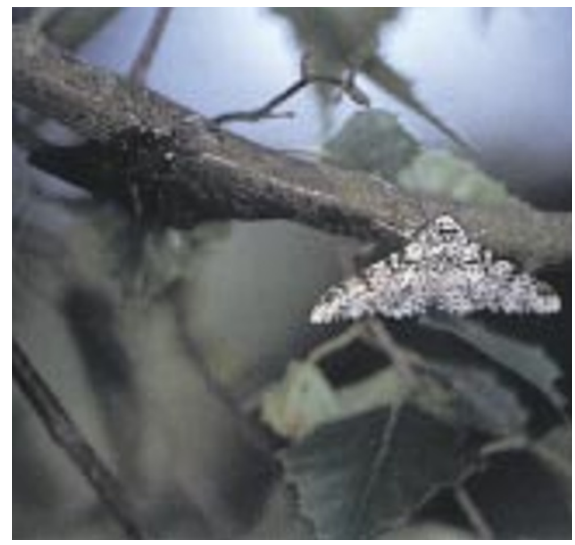

Cautionary tale: the classic account of industrial melanism in the peppered moth now looks flawed.

Michael Majerus's book, Melanism: Evolution in Action. Depressingly, Majerus shows that this classic example is in bad shape, and, while not yet ready for the glue factory, needs serious attention.

According to the standard textbook litany, before the mid-nineteenth century, all $B$. betularia in England were white moths peppered with black spots, a form called typica. Between 1850 and 1920, typica was largely replaced by a pure black form (carbonaria) produced by a single dominant allele, the frequency of which rose to nearly $100 \%$ in some areas. After 1950, this trend reversed, making carbonaria rare and typica again common. These persistent and directional changes implied natural selection. In a series of studies, this conclusion was verified by several investigators, most prominently Bernard Kettlewell of Oxford.

According to these workers, the evolution of colour was caused by birds eating the moths most conspicuous on their normal resting site - tree trunks. The increase in black moths was attributed to pollution accompanying the rise of heavy industry. A combination of soot and acid rain darkened trees by first killing the lichens that festooned them and then blackening the naked trunks. The typica form, previously camouflaged on lichens, thus became conspicuous and heavily predated, while the less visible carbonaria enjoyed protection and increased in frequency. After the passage of the Clean Air Acts in the 1950s, trees regained their former appearance, reversing the selective advantage of the morphs. This conclusion was bolstered by a geographical correlation between pollution levels and morph frequencies (carbonaria was most common in industrial areas), and most prominently by Kettlewell's famous experiments which showed that, after releasing typica and carbonaria in both polluted and unpolluted woods, researchers recaptured many more of the cryptic than of the conspicuous form. The differential predation was supported by direct observation of birds eating moths placed on trees. Finally, Kettlewell demonstrated in the laboratory that each form had a behavioural preference to settle on backgrounds that matched its colour.

Criticisms of this story have circulated in samizdat for several years, but Majerus summarizes them for the first time in print in an absorbing two-chapter critique (coincidentally, a similar analysis [Sargent et al., Evol. Biol. 30, 299-322; 1998] has just appeared). Majerus notes that the most serious problem is that $B$. betularia probably does not rest on tree trunks - exactly two moths have been seen in such a position in more than 40 years of intensive search. The natural resting spots are, in fact, a mystery. This alone invalidates Kettlewell's release-recapture experiments, as moths were released by placing them directly onto tree trunks, where they are highly visible to bird predators. (Kettlewell also released his moths during the day, while they normally choose resting places at night.) The story is further eroded by noting that the resurgence of typica occurred well before lichens recolonized the polluted trees, and that a parallel increase and decrease of the melanic form also occurred in industrial areas of the United States, where there was no change in the abundance of the lichens that supposedly play such an important role.

Finally, the results of Kettlewell's behavioural experiments were not replicated in later studies: moths have no tendency to choose matching backgrounds. Majerus finds many other flaws in the work, but they are too numerous to list here. I unearthed additional problems when, embarrassed at having taught the standard Biston story for years, I read Kettlewell's papers for the first time.

Majerus concludes, reasonably, that all we can deduce from this story is that it is a case of rapid evolution, probably involving pollution and bird predation. I would, however, replace "probably" with "perhaps". $B$. betularia shows the footprint of natural selection, but we have not yet seen the feet. Majerus finds some solace in his analysis, claiming that the true story is likely to be more complex and therefore more interesting, but one senses that he is making a virtue of necessity. My own reaction resembles the dismay attending my discovery, at the age of six, that it was my father and not Santa who brought the presents on Christmas Eve.

Occupying a quarter of the book, the Biston analysis is necessary reading for all evolutionists, as are the introductory chapters on the nature of melanism, its distribution among animals, and its proposed causes. Majerus, however, designed his book for both professional and lay readers, and this causes some unevenness in the material. The Biston story is sandwiched between less compelling chapters, including long sections on the basic principles of genetics and evolution, which can be skipped by evolutionists. Other discussions, involving melanism in ladybirds and other Lepidoptera, as well as 